\title{
MYRMECOPHILIC RELATIONSHIP OF PELLA \\ (COLEOPTERA: STAPHYLINIDAE) TO \\ LASIUS FULIGINOSUS (HYMENOPTERA: FORMICIDAE)
}

\author{
BY B. Hölldolber*, M. Möglich**, U. MaschWitz***
}

\section{INTRODUCTION}

A large number of staphylinid beetles are closely associated with ants and termites (for review see Wilson 1971, Kistner 1979). Those species living with ants are commonly called myremcophiles. At least a few (Atemeles, Lomechusa) have "broken" the communication code of their host species and are thereby able to become completely integrated in the social system of the ants (Hölldobler $1967,1970,1971)$. In an attempt to understand the evolutionary pathways of this highly specialized social parasitic behavior, we studied closely related staphylinid species that do not live within the ant society but instead occupy the foraging trails and garbage dumps of an ant nest.

Many of such myrmecophilous staphylinids can be found with the formicine ant Lasius fuliginosus and most of them belong to the genus Pella. Apparently these beetles are not endowed with the behavioral repertory that would enable them to live within the ant colony, although they seem to have a close ecological association with ants (Hölldobler 1972).

Kistner (1971) redefined the genus Zyras and raised the former subgenus Pella to generic rank. The first behavioral observations concerning Pella (=Zyras, Myrmedonia) were published by Wasmann $(1886,1930)$. He stated that these beetles feed on dead or disabled ants, but that they also lie in wait near the entrance and hunt ants returning to the nest. Furthermore, Wasmann pointed out that because of their generalized and primitive structure these beetles can be regarded as close to the ancestral forms from which some of the more specialized staphylinid myrmecophiles were derived.

\footnotetext{
*Department of Biology, Harvard University, Cambridge, Mass., USA.

**Present address: Am Löwentor 15, Darmstadt, W.-Germany.

***Fachbereich Biologie (Zoologie) der Universität Frankfurt, W.-Germany. Manuscript received by the editor October 19, 1981.
} 


\section{Material and Methods}

At our major study sites near Ochsenfurt, Riederau (both Bavaria, W.-Germany) and Gravenbruch (Hessen, W.-Germany) we found 12 staphylinid species associated with Lasius fuliginosus (Tab. 1). Our investigations concentrated on the genus Pella (mainly $P$. funesta, $P$. laticollis and $P$. cognata). Since the myrmecophilous behavior of these species was found to be very similar we will refer to the individual species only where necessary. In fact, when observing the beetles in the field it was usually not possible to identify the species precisely. We made additional observations with Pella humeralis, which can be found with L. fuliginosus, but which often also occurs near the nests of Formica polyctena (Wasmann 1920; Kolbe 1971).

The field observations were conducted throughout the years 1967-1969, and sporadically in 1970-1973. In an attempt to follow the life cycle of the beetles in the laboratory we set up a large colony of Lasius fuliginosus in a laboratory nest. The culture and maintenance of these ants over a longer period of time was particularly difficult, because $L$. fuliginosus constructs carton nests with the aid of a special symbiontic fungus (Cladosporium myrmecophilum). A detailed description of the nest building behavior of $L$. fuliginosus and of the laboratory nest is given in Maschwitz and Hölldobler (1970).

In order to measure quantitatively possible trophallactic feeding of the myrmecophiles by their host ants, tracer experiments were carried out using the radioisotope ${ }^{32} \mathrm{P}$ mixed with honey-water. The quantity of marked food taken up by the ants was reflected in the counts per minute which were determined with a standard Geiger-

Table 1

Staphylinids found near one nest of Lasius fuliginosus.

\begin{tabular}{ll}
\hline Pella laticollis & Oxypoda vittata \\
Pella lugens & Rugilus rufipes \\
Pella cognata & Thiasophila inquilina \\
Pella funesta & Homoeusa acuminata \\
Pella humeralis & Sipalia circellaris \\
& Atheta fungi \\
& Atheta sodalis
\end{tabular}


were lying motionless in the loose material and showed a kind of "dormance posture": the abdomen was bent over its back, with the legs and antennae folded tightly to the body. On warmer days, however, the beetles exhibited high locomotory and flight activity, and in the laboratory they showed a strong positive phototaxis. During this period we frequently observed beetles copulating in the laboratory nests. Toward the end of April the sexual behavior and flight activities ceased. In the laboratory as well as in the field the beetles were now active primarily during the night, while during the daytime they clustered under shelters near the Lasius fuliginosus nest. Only occasionally were we able to spot a beetle outside the shelters at daytime.

Also near the end of April we found the first beetle eggs in the "garbage dumps" of the laboratory nest of $L$. fuliginosus, and by early May the first Pella larvae had hatched. The larvae developed quite rapidly, so that in mid-May we found the first pupae in the "garbage dumps" of the ant nests, even though larvae could still be found throughout the months of June and July. In June the mortality of adult beetles in our laboratory nest increased markedly and in late July and August the first young beetles eclosed from their pupae. These beetles, as well as those collected in the field in early August, exhibited strong positive phototaxis and high flight activity for a few days. After this short period, however, the beetles were primarily active at night and during the day they stayed in shelters. Finally, in October, the number of beetles found outside the ant nest declined markedly and by November no more beetles could be found outside the nest. In December we excavated to $L$. fuliginosus nests. In both nests we found several Pella beetles in "dormance position" covered by loose nest material of the peripheral nest chambers and on the ground inside the nest tree trunk. Presumably these beetles were overwintering within the Lasius fuliginosus nest until their activity period would start again in early spring the coming year.

From these observations we propose the following life cycle for Pella funesta: in early spring the adult beetles deposit eggs near the ants' "garbage dump" area. The larvae develop in the "garbage dump", pupate during the period from May to July and between July-August the adult beetles eclose. After eclosion the young beetles apparently migrate, as indicated by the short period of high diurnal locomotory and flight activity. After this period the beetles 
forage near the $L$. fuliginosus nest during the night and stay in shelters during the day. They overwinter in dormancy inside the $L$. fuliginosus nest. With the end of winter the beetles enter a second diurnal activity phase during which mating takes place. After reproduction the beetles die, normally a few weeks before the new beetle generation ecloses in June.

The behavior of the larvae of Pella

The description of the behavior of the larvae is primarily based on observations in the laboratory. In the field and in the laboratory nest, the larvae were almost exclusively found near or in the "garbage dumps" of the $L$. fuliginosus nests. We frequently observed the larvae feeding on dead ants (Fig. 1B). During feeding the larvae always attempted to stay "out of sight" either by remaining entirely beneath the booty and devouring it from below or by crawling inside the dead ant's body. Occasionally 2-4 larvae could be observed feeding on the same ant cadaver. But when they became too crowded they frequently attacked each other, sometimes resulting in one larvae eating the other (Fig. 1C).

When ants encountered the larvae they usually attacked them. Almost invariably the larvae reacted with a typical defense behavior. They raised their abdominal tip towards the head of the ants. Usually the ant responded by stopping the attack and palpating the larva's tip (Fig. 1A). In most cases this short interruption was enough to allow the larvae to escape. We observed hundreds of such encounters between ants and Pella larvae; only a few ended fatally for the larvae.

Histological invesigations revealed that the Pella larvae have a complex dorsal glandular structure with a reservoir near the abdominal tip in the second last segment. In addition we found single cell glands positioned dorso-laterally in each segment. Similar glandular structures had previously been found in larvae of the myrmecophile staphylinids Atemeles and Lomechusa, and circumstantial evidence strongly indicated that in these species the glands produce so-called pseudopheromones which release adoption behavior in the host ants (Hölldobler 1967). We have no evidence to suggest that these glands have a similar function in Pella. However, it is possible that the more complex glandular structure at the abdominal tip, produces an appeasement secretion by which the aggressiveness of attacking ants can be briefly blunted. 

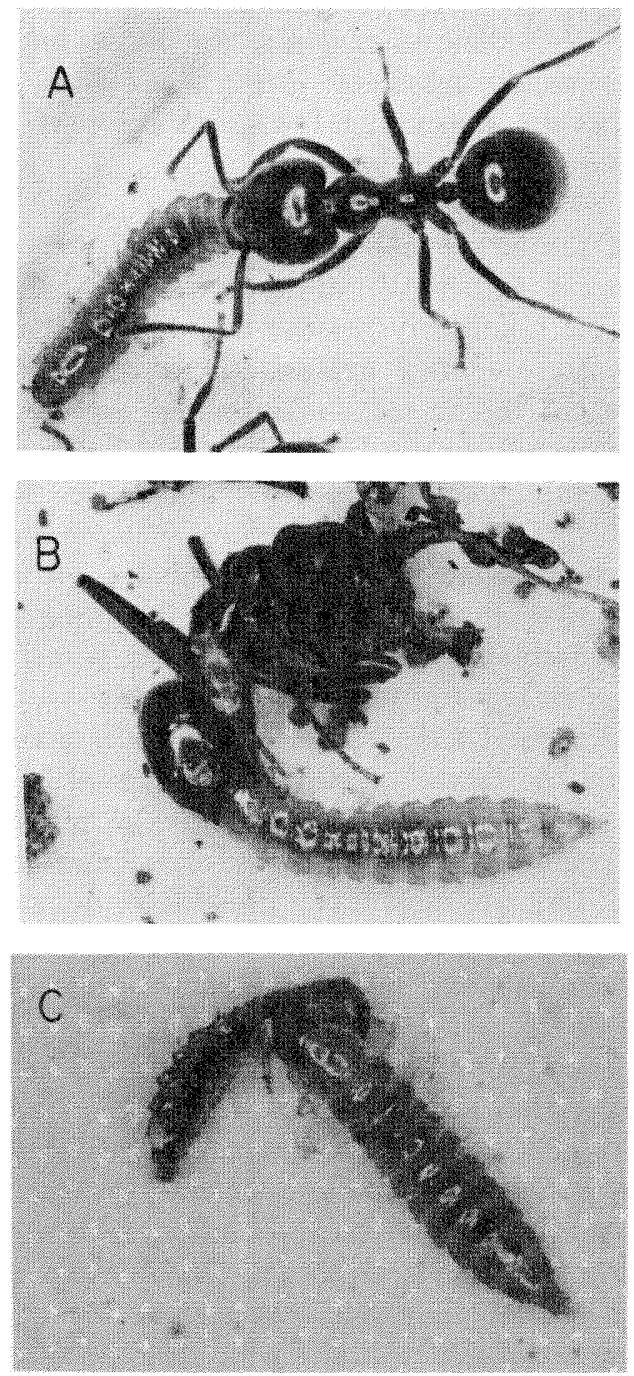

Fig. 1 Behavior of the larvae of Pella. A) Larva presenting abdominal tip to an attacking worker of Lasius fuliginosus. The ant interrupts attack and licks at the larva. B) Larva feeds on dead ant. C) Cannibalistic behavior of Pella larvae. 
In any case, Pella larvae are able to come into close contact to workers of $L$. fuliginosus without being attacked, especially when the temperature is low $\left(14-17^{\circ} \mathrm{C}\right)$. Under those circumstances we have seen the beetle larvae licking the cuticle of live ants, including even the mandibles and mouthparts. This led us to the question of whether the beetle larvae occasionally solicit regurgitation in ants. In order to investigate this possibility ants were fed with honeywater labeled with the isotope ${ }^{32} \mathrm{P}$ and then housed together with beetle larvae. For each sample we kept 30 radioactive ants with 5 beetle larvae in plastic containers $(10 \times 15 \mathrm{~cm})$ with a moist gypsum bottom. One experimental series was conducted in a temperature range of $14.5-16.5^{\circ} \mathrm{C}$, the other in $20-23^{\circ} \mathrm{C}$. After 24 hours we measured the amount of radioactivity in each individual ant and larva. No significant amount of radioactivity had been transferred from the ants to the larvae, except in container 6 , where one ant was found dead and obviously partly eaten by the larvae. Since the amount of radioactivity carried by some of the larvae was only very slightly above the background activity, we concluded that it was transferred by contamination. From this experiment it appears that the Pella larvae do not solicit regurgitation in ants. Their main food source seems to be dead ants or debris of the ants. In fact, they can easily be raised by keeping them entirely separated from living ants, just by feeding them regularly with dead ants.

Predatory behavior of adult beetles

Since Wasmann's early observations $(1886,1920,1925)$ very little has been reported concerning the biology of the myrmecophilous Pella. Wasmann reported that all species he had studied ( $P$. humeralis, $P$. funesta, $P$. cognata, $P$. similis, $P$. lugens and $P$. laticollis) live with Lasius fuliginosus, and only $P$. humeralis can also be found with species of the Formica rufa group. According to Wasmann all these Pella species prey on ants, concentrating especially on disabled ants. In addition Wasmann observed that the beetles are active primarily during the night. In a more recent publication Kolbe (1971) failed to find a predatorial behavior in $P$. humeralis and concluded that this species primarily feeds on dead ants. Similar observations were made with Pella japonicus, which lives with Lasius spathepus $(=\mathrm{L}$. fuliginosus var. spathepus Wheeler) (Yasumatsu 1937; Kistner 1971). Kistner also observed that these beetles "ate small insects that are being transported by the 
ants". However, he could not "see the Pella eating live ants or fighting any of the ants on the trail".

Our observations of Pella funesta, $P$. laticollis and $P$. humeralis confirmed that these species live as scavengers, feeding on dead or disabled ants and debris discarded by the ants. However, we also observed these beetles acting as very effective predators on the ants. Most of the following studies were made with $P$. laticollis and $P$. funesta.

During the main foraging season from May to October Lasius fuliginosus is active day and night. Foragers travel along well established trunk trails to feeding sites which are sometimes more than $40 \mathrm{~m}$ distant. At daytime we only occasionally saw Pella beetles moving along or nearby the trail. However, when we watched the trunk trails with a flash light at night many Pella were seen running along the ants' foraging routes. Although most beetles were found within a range of $5 \mathrm{~m}$ from the nest tree of $L$. fuliginosus, we also found beetles on the trunk trail as far as $22 \mathrm{~m}$ away from the nest.

On 6 different occasions we witnessed Pella beetles hunting $L$. fuliginosus workers at night on the foraging trail. When an ant was killed it was dragged a few centimeters away from the trail and eaten under a shelter, sometimes by several beetles simultaneously.

More detailed observations on the behavioral interactions of Pella and L. fuliginosus were made in the laboratory. As long as enough dead ants were available at the ants' nest midden, the beetles showed no predatory behavior at all, limiting themselves to a diet of ant cadavers (Fig. 2A). But when the beetles were starved for a few days and then placed together with ants in an observation arena, the predation by Pella became strikingly prominent, although the time of onset was often very unpredictable. We saw the beetles hunting during the daytime, but we observed such activity most frequently in the evening or at night. The beetles chased after individual ants and pursued them through approximately $2-6 \mathrm{~cm}$ (very rarely through longer distances than that). When the beetle moved directly behind the ant it attempted to mount it and insert its head between the ant's head and thorax. When attacked the ant usually reacted by suddenly stopping and pressing the femur rapidly and tightly to its body (Fig. 5). Often this reaction threw the beetle off the back of the ant, allowing the ant to escape. In one series of observations we counted 178 beetle onslaughts on $L$. fuliginosus workers within a period of 3 hours; of these, only 9 attempts (5\%) were successful. 

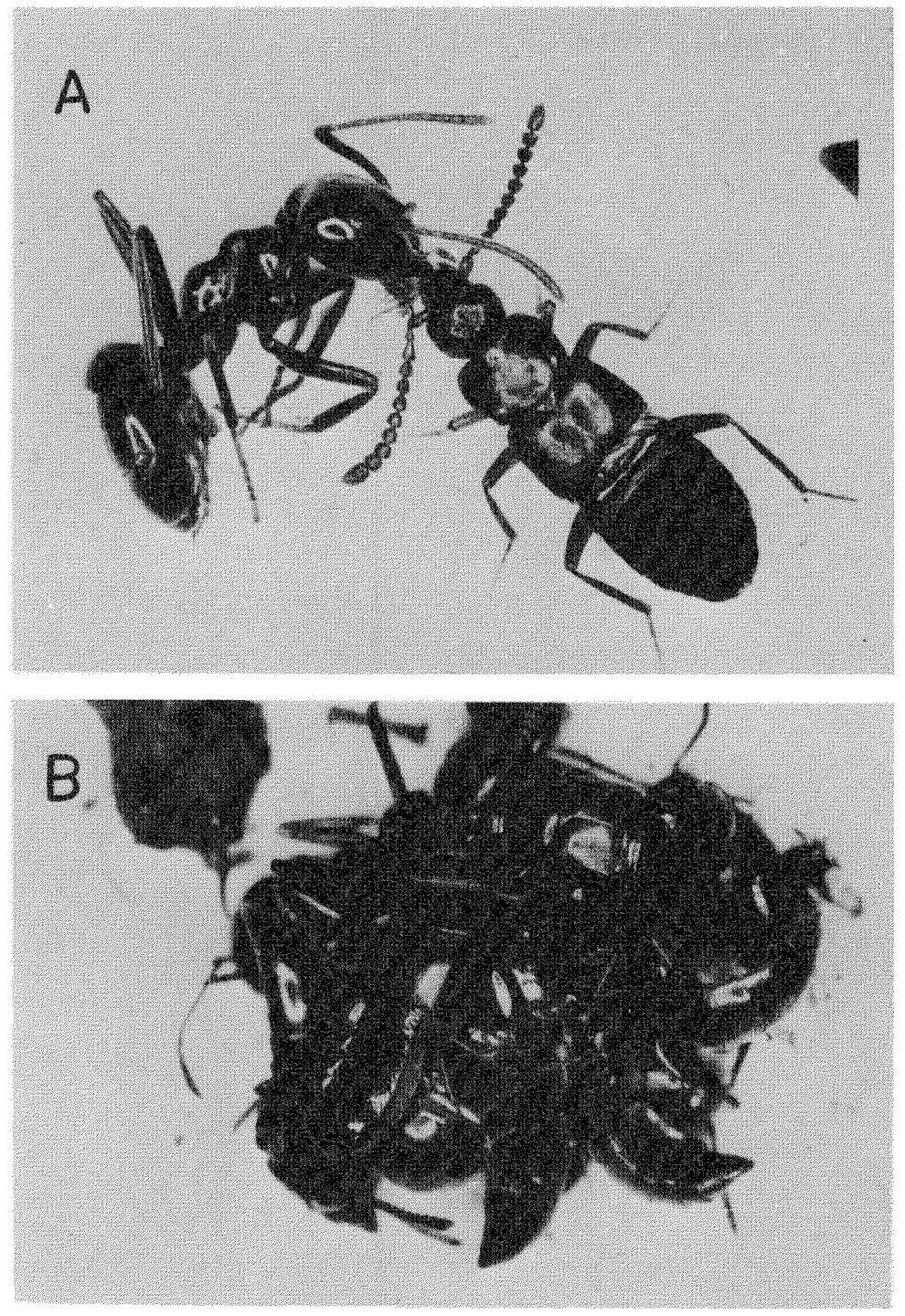

Fig. 2 A) Pella beetle feeding on dead L. fuliginosus worker. Frequently the beetles lick first the mouth parts of the ants, before tearing the cadavers apart. They might be attracted to mouthparts by sweet remainders of honeydew. B) Cluster of Pella beetles around a prey object. 

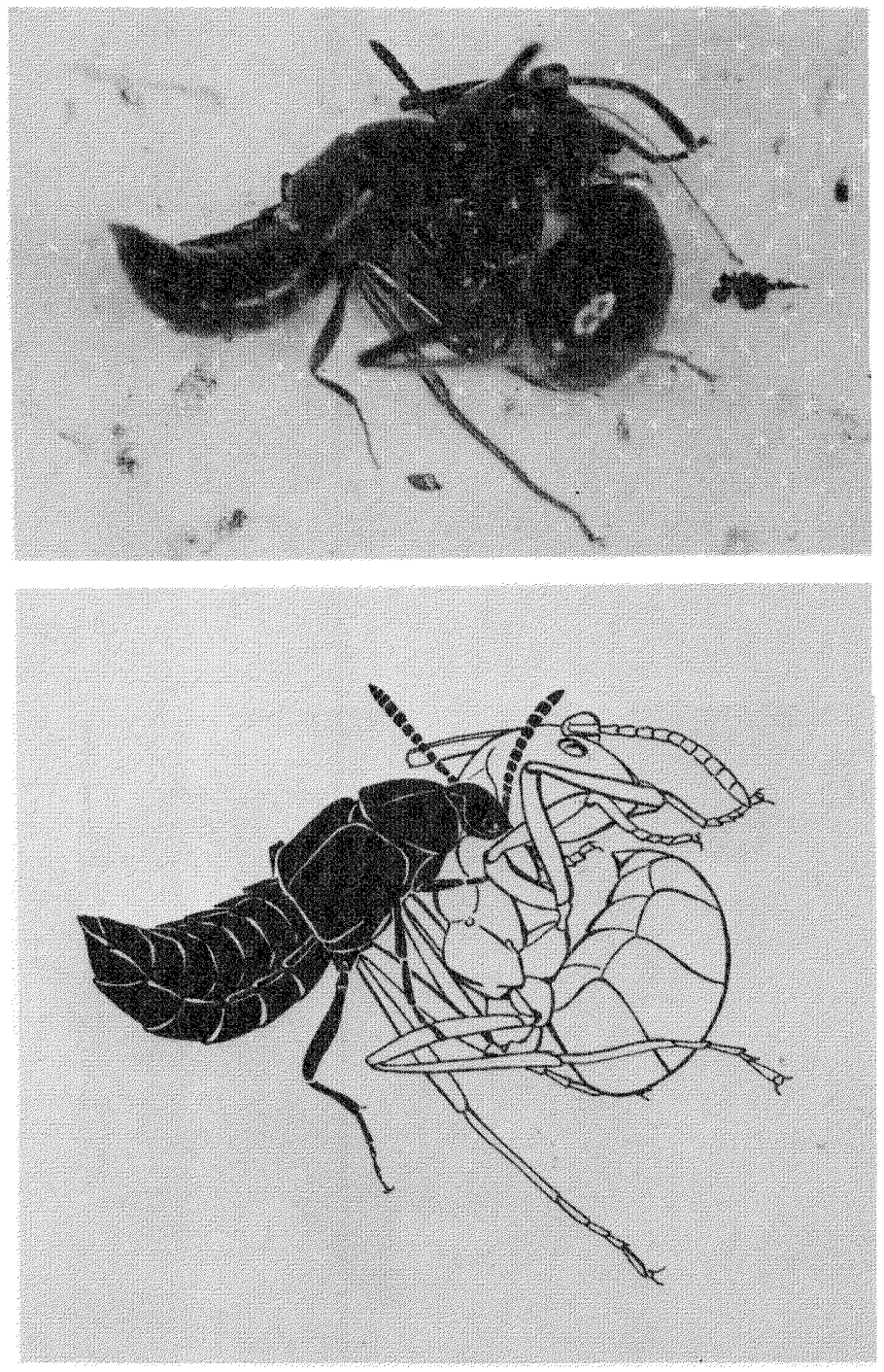

Fig. 3 Photograph and drawing of Pella attacking live worker of L. fuliginosus. 
The hunting behavior of the beetles was always the same in $P$. laticollis, $P$. funesta and $P$. humeralis: the beetle attacked from behind and always attempted to insert its head between the head and thorax of the ant. We inspected several ants which had just been immobilized by an attack of a beetle and found that in most cases the pronotum was widely separated from the head and usually the oesophagus and connectives of the nervous system were cut.

Occasionally we observed 2-3 beetles chasing behind one ant (Fig. 4). Once the ant was caught by a beetle the other beetles joined in subduing and killing the ant. Although individual beetles often tried to drag the prey away from the rest of the "hunting pack", usually several beetles fed on the prey simultaneously. No aggression among the beetles was observed in this situation. However, when the beetles were starved for several days and were kept without ants, they occasionally chased each other, jumping on each other's back as they normally did when hunting ants. But we never saw cannibalistic behavior among the adult beetles, even when the beetles were densely crowded around a prey object (Fig. 2B).

Defense and appeasement behavior in adult beetles

Defense with tergal gland secretion:

Usually the Pella beetles run around with their abdomen curved slightly upwards. When encountering an ant, the beetles flex the abdomen even more strongly. This is a typical and frequently described behavior of many staphylinid myrmecophiles and is commonly considered a defense response (Wasmann 1886, 1920; Jordan 1913; Patrizi 1948; Koblick and Kistner 1965; Pasteels 1968; Hölldobler 1970, 1972; Kolbe 1971). It has been suggested that during this abdominal flexing the beetles discharge secretions from their tergal gland (Jordan 1913; Kistner and Blum 1971).

The tergal gland is located between the sixth and seventh abdominal tergites (Fig. 6), and is unique to the subfamily Aleocharinae (Jordan 1913; Pasteels 1968). The chemistry of the tergal gland secretions of several species has been investigated and found to be extraordinarily diverse (Blum et al. 1971; Brand et al. 1973; Kolbe and Proske 1973).

Kistner and Blum (1971) suggested that Pella japonicus and possibly also $P$. comes, both of which live with Lasius spathepus, produce citronellal in their tergal glands. This substance is also a 

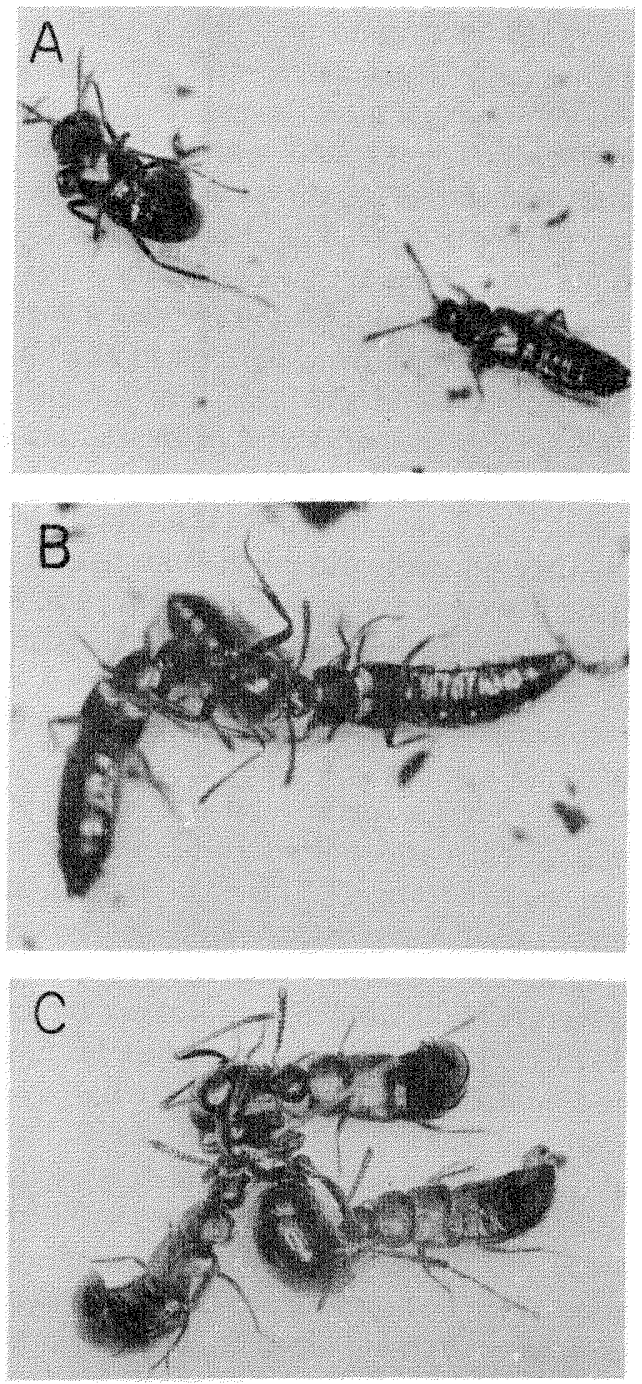

Fig. 4 Sequence of group hunting behavior of Pella. A) Two beetles chase a forager of $L$. fuliginosus. One of the beetles is jumping on the back of the ant. B) The ant has been captured and subdued by both beetles. C) A third beetle is joining the hunting group. 

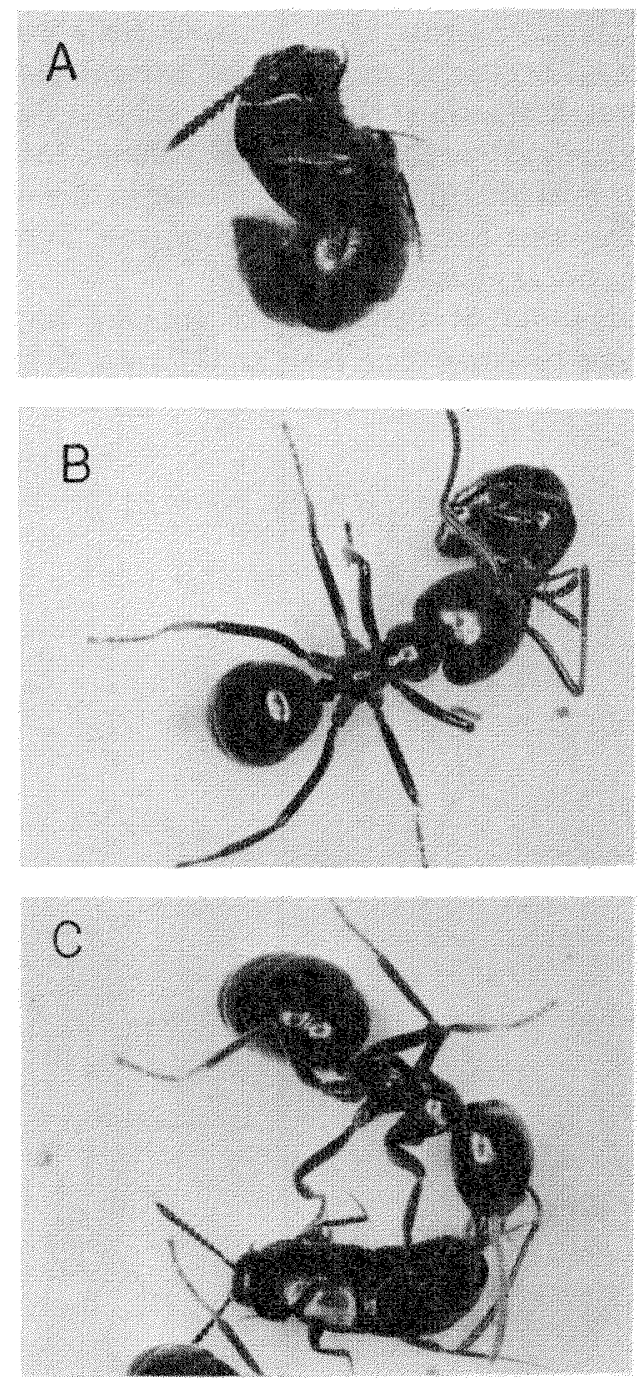

Fig. 5 A) Pella in "death feigning" position. B) A "death feigning" beetle is carried around by a $L$. fuliginosus worker. C) Pella presents abdominal tip to attacking $L$. fuliginosus worker. The ant licks at the abdominal tip. 
major compound of the mandibular gland secretions of their host ants, for which it functions as an alarm pheromone. Although no Pella tergal gland contents were available for chemical analysis, because irritated beetles seemed to smell like the ants' mandibular gland secretion, Kistner and Blum speculated that Pella produce in their tergal glands citronellal and thereby mimic the alarm pheromone of their host ants. They suggested that in this way the beetles can "cause the ants to reverse their direction; a reaction which allows the myrmecophiles to escape".

Our investigations of the defensive strategy employed by the European Pella towards their host ants Lasius fuliginosus led to

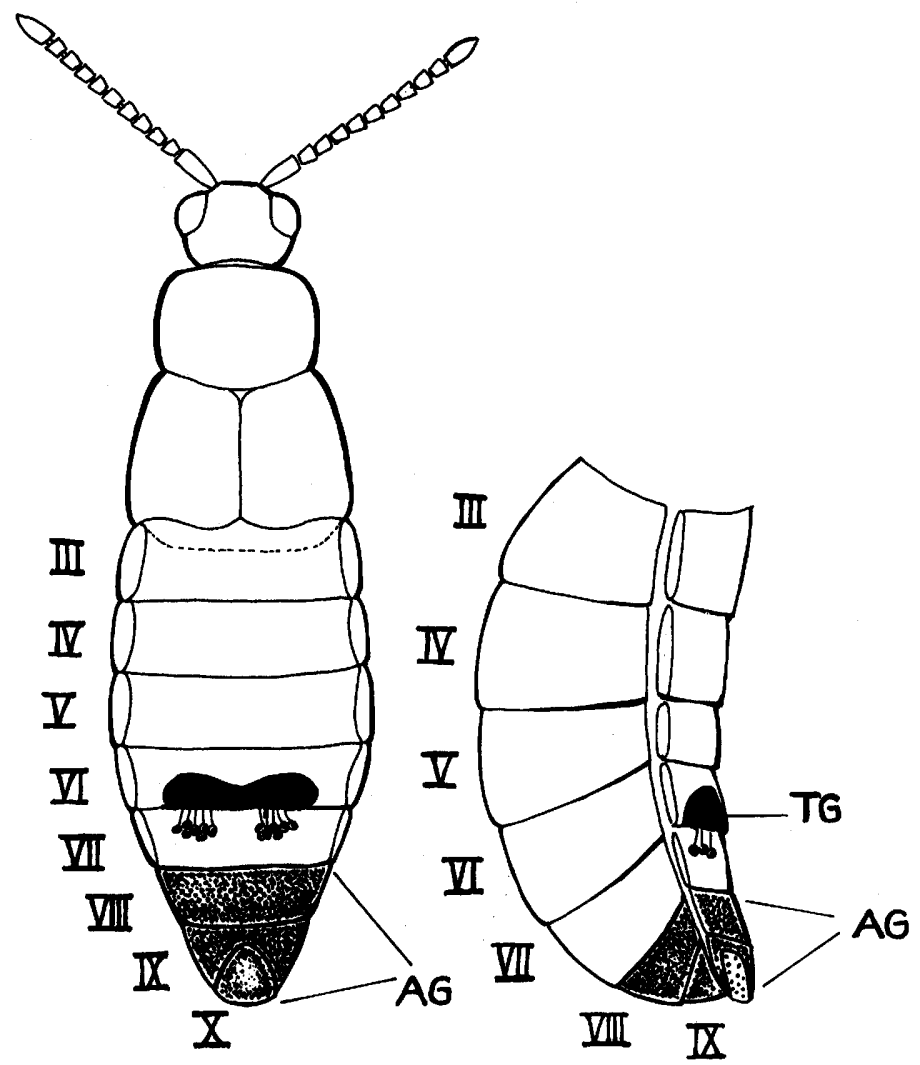

Fig. 6 Schematical drawing of a Pella beetle indicating the position of the exocrine glandular complexes. TG: tergal gland; AG: appeasement gland complex. 
different results. Pella laticollis, when irritated mechanically discharges a pungent smelling brownish secretion from its tergal gland that shows acidic reactions. Only when the beetles were severely attacked and firmly grasped on their appendages by the ants, could we smell the tergal gland secretion. We never observed the beetles employing tergal gland secretion when they were attacking ants. Ants contaminated with tergal gland secretion usually exhibited a repellent reaction, releasing the grip on the beetles and grooming and wiping their mouth parts and antennae on the substrate. But the beetles had to escape quickly, because other ants close by became alerted and were rapidly approaching the scene, apparently alarmed by the ants' alarm pheromone. We noticed that beetles that were attacked by $L$. fuliginosus workers often smelled somewhat like the ants' mandibular secretions, but the beetles' tergal gland secretions clearly smelled differently. Conceivably, some of the attacked beetles were contaminated with the ants' strongly smelling mandibular gland secretions.

Our chemical analysis of the tergal gland secretions of $P$. laticollis did not reveal a resemblance to the mandibular gland secretions of L. fulginosus, whose major compounds are farnesal, 6-methyl-5hepten-2-one; perillene and dendrolasin, a furan (Quilico et al 1957; Bernardi et al 1967). When we treated the tergal gland section with 2,4-dinitrophenyl-hydrazine, we obtained an orange-yellowish precipitate. This was subjected to thinlayer chromatography in two separate systems. In each system we obtained two spots. The Rf values and the color reaction, when treated with ammonia vapour, identified them as dinitrophenylhydrazones of p-benzoquinone and p-toluquinone. Furthermore, the chromatography of the hydroquinones obtained from the secretion by reduction with $\mathrm{SO}_{2}$ also demonstrated the presence of p-benzo- and p-toluquinone in the tergal gland secretion.

For comparison we used thinlayer chromatography to analyze the dinitrophenylhydrazones of the tergal gland secretion of several other aleocharine staphylinds found near the nests of L. fuliginosus. Pella humeralis, Atheta fungi and Sipalia circellaris also produce benzo- and toluquinone; in Oxypoda vittata we found only toluquinone.

In addition Kolbe and Proske (1973) identified isovaleric acid in the tergal gland secretion of $P$. humeralis, and with the aid of gas chromatography we detected saturated hydrocarbons and short 


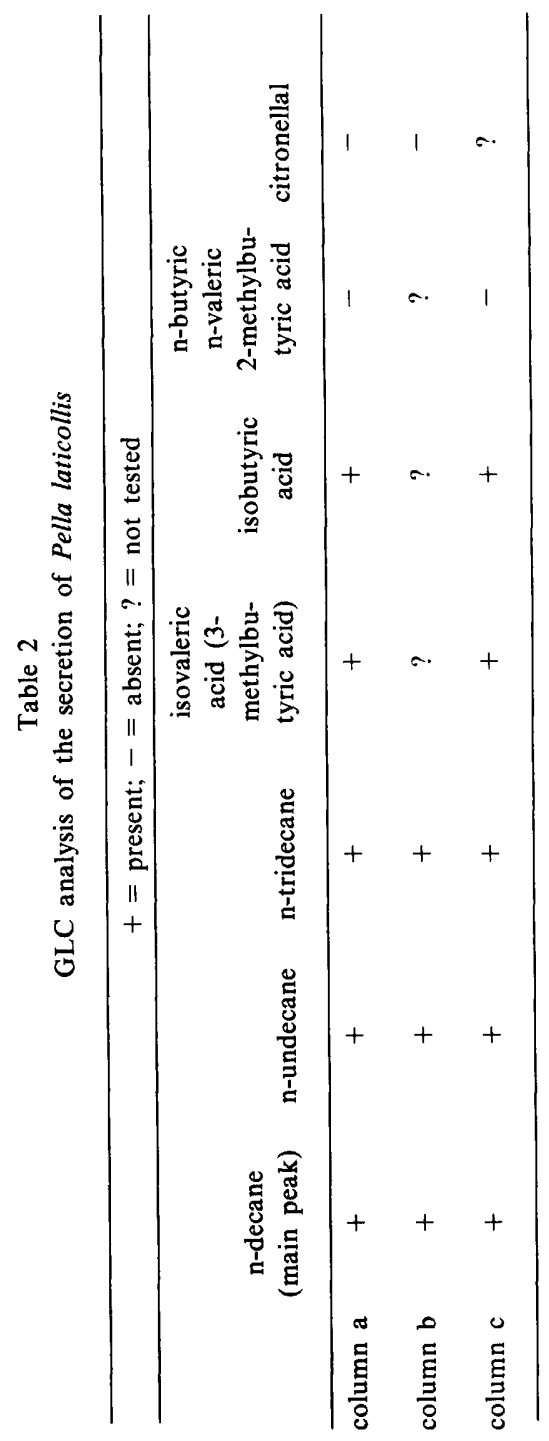


chained fatty acids in the secretion of $P$. laticollis (Tab. 2). However, in none of the species could we find citronellal.

The common presence of quinones in the tergal gland secretions of Pella and the related aleocharine species agree with the previous findings by Blum et al (1971), who found the tergal gland secretion of Lomechusa strumosa to contain benzoquinone, methyl-benzoquinone, ethyl-benzoquinone and n-tridecane, the latter substance accounting for more than $80 \%$ of the volatiles detected in the secretion. In addition Brand et al. (1973) analyzed the tergal gland secretion of Drusilla canaliculata, also an aleocharine beetle, finding quinones and hydroquinones together with alkanes, saturated and unsaturated aliphatic aldehydes. Pasteels (1968) demonstrated that D. canaliculata effectively employs the tergal gland secretion as a repellent-defense weapon against ants in a similar fashion as we described it for Pella.

Although we could not find any resemblance of the Pella tergal gland secretions to the mandibular gland secretions of Lasius fuliginosus, it was noteworthy that the Pella secretions contained undecane, a hydrocarbon commonly found in the Dufour's glands of formicine ants (for review see Blum and Hermann 1978) and considered to be an alarm pheromone in L. fuliginosus (Dumpert 1972). However, isolated tergal gland secretions of $P$. laticollis elicited a repellent reaction rather than an alarm response in $L$. fuliginosus. Apparently the repellent effect of the quinones in the secretions is stronger than a possible alarming effect released by undecane. In fact, when the ant's antennae were directly contaminated with the beetles' tergal gland secretions the antennae were hanging almost motionless and flabby and the ant appeared disoriented for several minutes. From all our laboratory tests it appears obvious that the tergal gland secretions of Pella functions as a powerful chemical defense weapon against attacks by ants.

Appeasement behavior:

When foraging on the ants' "garbage dumps" or running along the ants' trails, Pella frequently encounter ants. Yet we were impressed by the scarcity of their application of the tergal gland defensive system. Much more frequently the beetles employed an appeasing defensive strategy, and the repellent defense seemed to be employed only as a last resort. 

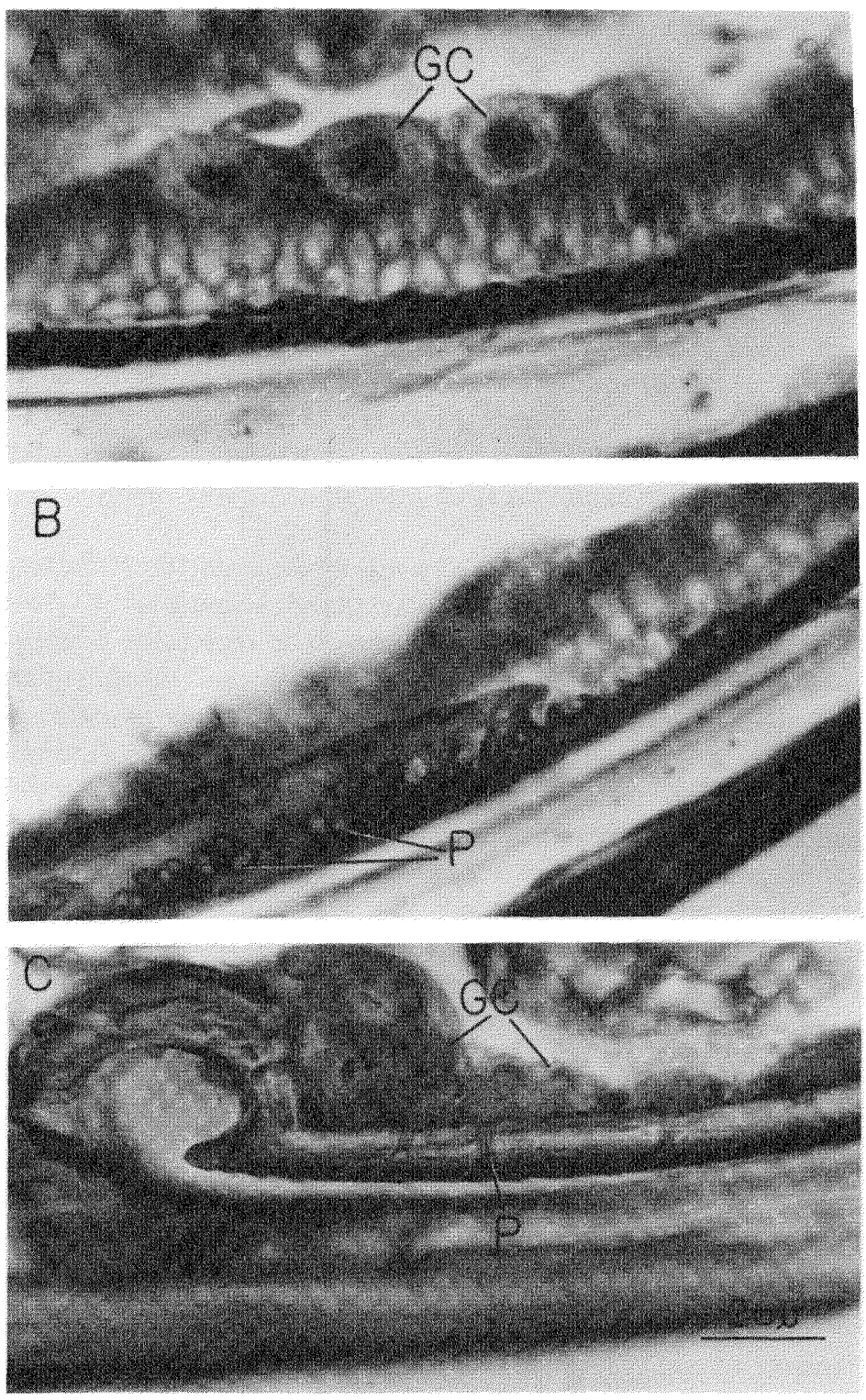

Fig. 7 A,B) Transversal section through glandular epithelium in 9th sternum of $P$. humeralis. C) Sagital section through sternal gland in 7 th sternum of $P$. humeralis. GC: glandular cell; P: pore in cuticle. 
It was especially common in early spring, when most of the beetles were found close to the entrance of the ants' nest, that the beetles showed "death feigning" behavior, when attacked by ants. They fell to the side, the legs and antennae folded tightly to the body and the abdomen curved upwards (Fig. 5A). The ants either ignored these motionless beetles or carried them around and finally discarded them on the "garbage dump". But only rarely did they injure the beetles (Fig. 5B).

Later in the year, when the activity of ants and beetles was much higher, the beetles employed a different appeasement technique. As mentioned before, we only very rarely saw the discharge of tergal gland secretions by the beetles, although every time they encountered ants they flexed their abdomen and pointed with the abdominal tip toward the head of their adversaries. Usually the ants responded by antennating the tip and briefly licking it (Fig. 5C). This ordinarily slowed down the ants' aggression and the beetles used the ants' distraction to escape. Occasionally, when the ants remained very persistent, a white, viscous droplet appeared at the abdominal tip, whereupon the ants usually very eagerly licked it up. This appeasing defensive behavior was much more common during the interactions between Pella and Lasius fuliginosus than the repellent defense. For a series of simulation experiments we cut off the last 3 segments of the abdomen of freshly killed $P$. laticollis, sealed the cut with wax, pinned the segments on dissecting needles and presented these "dummies" to the ants. In a total of 60 tests (using 3 different dummies) the ants interrupted their run in 47 cases $(78 \%)$ and licked the abdominal tip briefly.

Histological investigations revealed that the abdominal tips of Pella are batteries of exocrine glandular structures, all of which together we call the appeasement gland complex. In the following section we give a brief description of the glands which could be involved in the appeasement behavior.

The most comprehensive study of the glandular morphology of some termitophilous and myrmecophilous aleocharine beetles has been published by Pasteels (1968). From this work we learned that these beetles possess a surprising variety of exocrine glandular structures and that various species can differ considerably in their glandular systems. In the four species of Pella ( $P$. cognata, $P$. funesta, $P$. humeralis, $P$. laticollis) we investigated, we did not find major differences, although $P$. humeralis appeared to be somewhat 


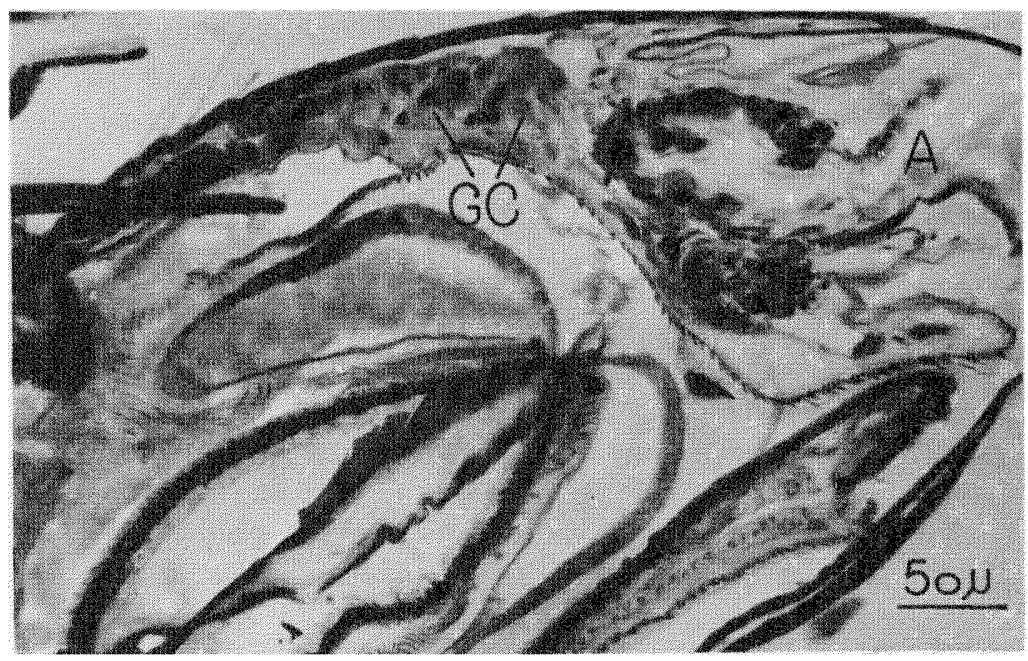

Fig. 8 Sagital section through abdominal tip of $P$. humeralis. GC: glandular cells under 10th tergite near anus. A: anus.

more richly endowed with hypodermal glandular cells, especially in the area of the paratergites.

In staphylinid beetles the first fully developed abdominal segmental ring (tergite plus sternite) is usually considered to be the $3 \mathrm{rd}$ abdominal segment (Blackwelder 1936). All Pella species have a well developed compound tergal gland between the 6th and 7 th tergites (Fig. 6) as described by Jordan (1913), Pasteels (1968) and Hölldobler (1970). We have also detected glandular cells located primarily in the 7th segment, which Pasteels (1968) calls postpleural glands. According to Pasteels the glandular channels associated with these cells open dorsolaterally through the pleural membrane between the 7 th and 8 th segments. Pasteels could clearly see these openings in several species (for example in Gyrophanaena affinis), but not in Pella (Zyras) humeralis. In a series of longitudinal, transversal and frontal sections, we too were unable to detect the external openings of these glandular cells.

At the anterior edge of the 4th, 5th, 6th and 7 th sternites are found clusters of glandular cells that open through pores in the cuticle (Fig. 7A). They are especially well developed in the 7th sternite. Pasteels (1968) assumes that the secretions of these glands 

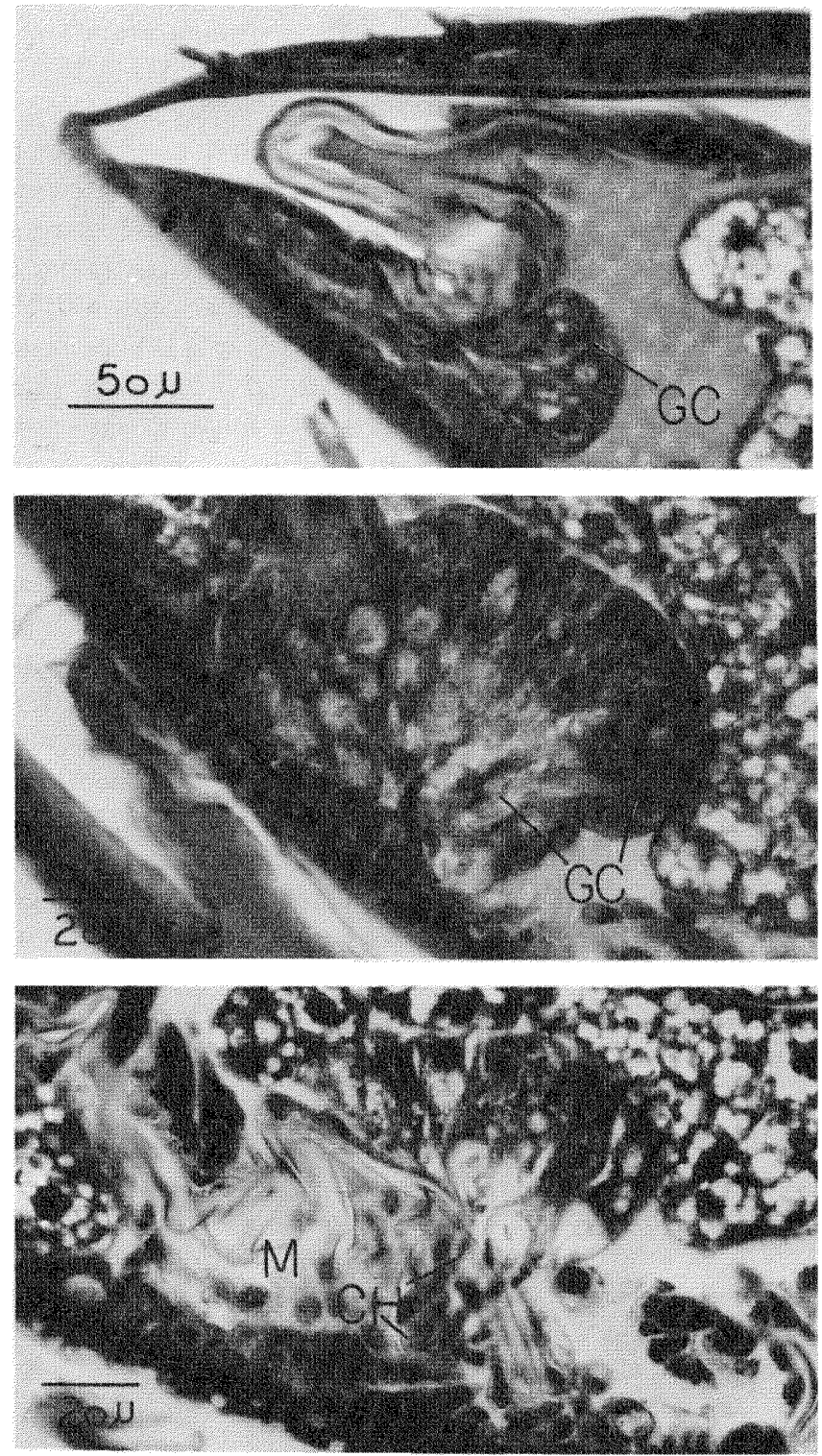

Fig. 9 Sagital sections through abdominal tip of Pella laticollis female. GC: glandular cell clusters; M: membrane; $\mathrm{CH}$ : glandular channels. 
serve primarily for lubrication to alleviate friction between the sternal sclerites when the beetles flex their abdomen. But more than any other of the abdominal segments the last 3 tergites (VII, IX, X) (Fig. 6) and the 8th and 9th sternites are richly endowed with glandular epithelia, the individual cells of which open through pores in the cuticle (Fig. 1B, 1C). The last two segments can be telescoped with especial ease into the preceding segments, and during the appeasement process the beetles often move them slightly back and forth. Furthermore, there are clusters of glandular cells with longer channels under the 10th tergite near the anus (Fig. 8). They resemble the type of cells that Hölldobler (1971) located in the same position in Atemeles and called pygidial glands. We have, however, abandoned this term, because it is very confusing, especially in the Aleocharinae, where the last visible tergite is usually not the 8th tergite (often called pygidium in the Coleoptera) but the 10th tergite.

In addition to these hypodermal glandular structures, females and males possess special exocrine glandular complexes that might be involved in the reproductive processes but which could also play a role in the myrmecophilous behavior of the beetles. In the 9th sternite of females there are several clusters of glandular cells, the channels of which open through the intersegmental membrane at the tip of the abdomen and near the oviduct (Fig. 9). Males have similar glands in the 9th sternite which also open through the intersegmental membrane near the posterior part of the genital chamber (Fig. 10). Furthermore, males possess a very large glandular complex, consisting of numerous tightly packed glandular cells each connected with a long channel that open dorsally in bundles through a membrane at the genital chamber (Fig. 11). We assume that the secretions of this gland flow into the genital chamber. Females do not have this gland, but the spermathecal gland has a very smilar appearance.

Finally, the hindgut might also be involved in the appeasement process. On several occasions we observed that beetles, upon presenting their abdominal tip to the ants, released a droplet at the anus that was licked up by the ants.

\section{Discussion:}

Some of the most advanced myrmecophilic relationships are found in the aleocharine beetles Lomechusa and Atemeles. We 

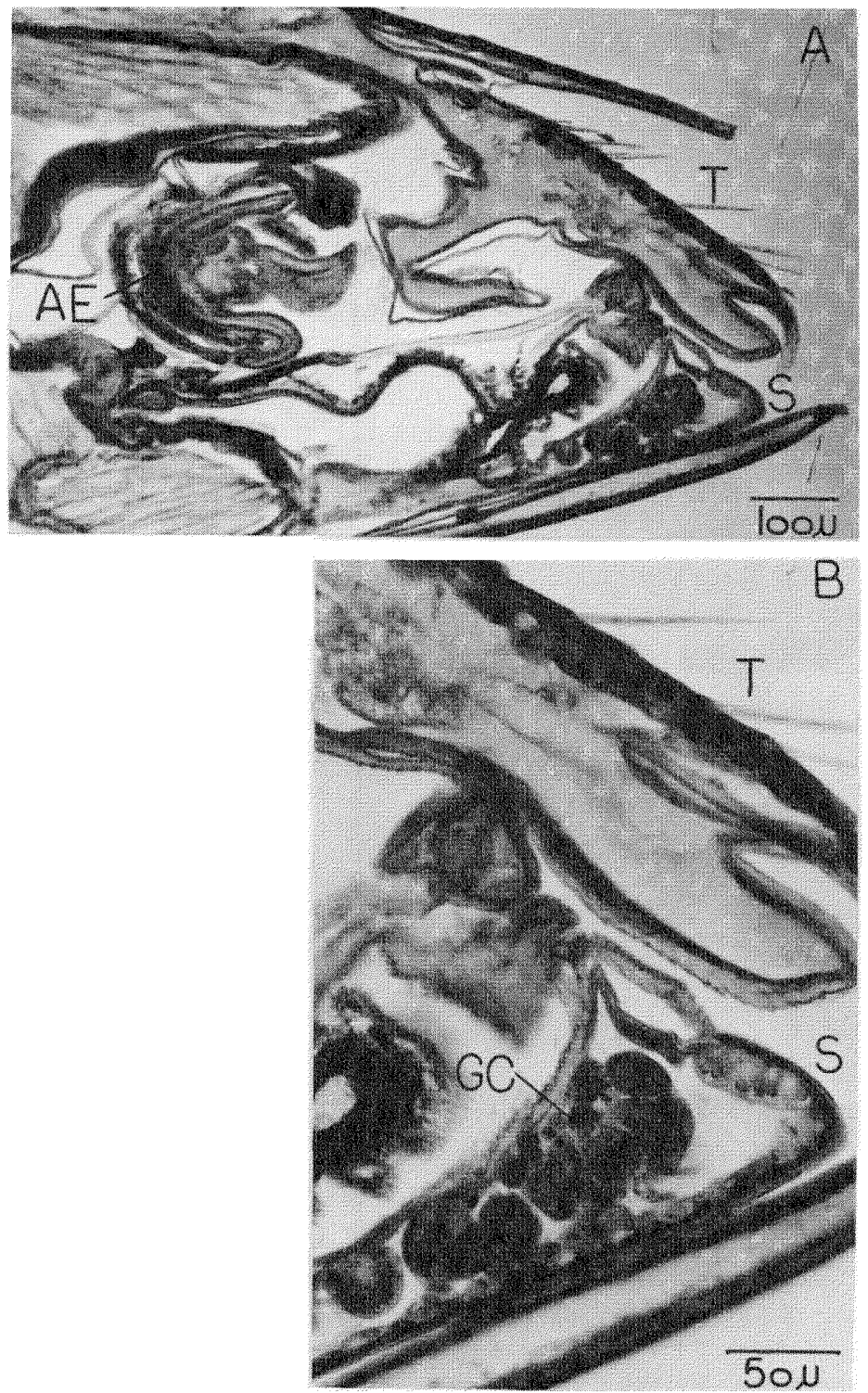

Fig. 10 A) Sagital sections through the abdominal tip of $P$. humeralis male. T: 9th and 10th tergite; S: 9th sternite; AE: aedeagus. B) Close-up of sagital section through 10th tergite and 9th sternite. GC: glandular cell clusters. 

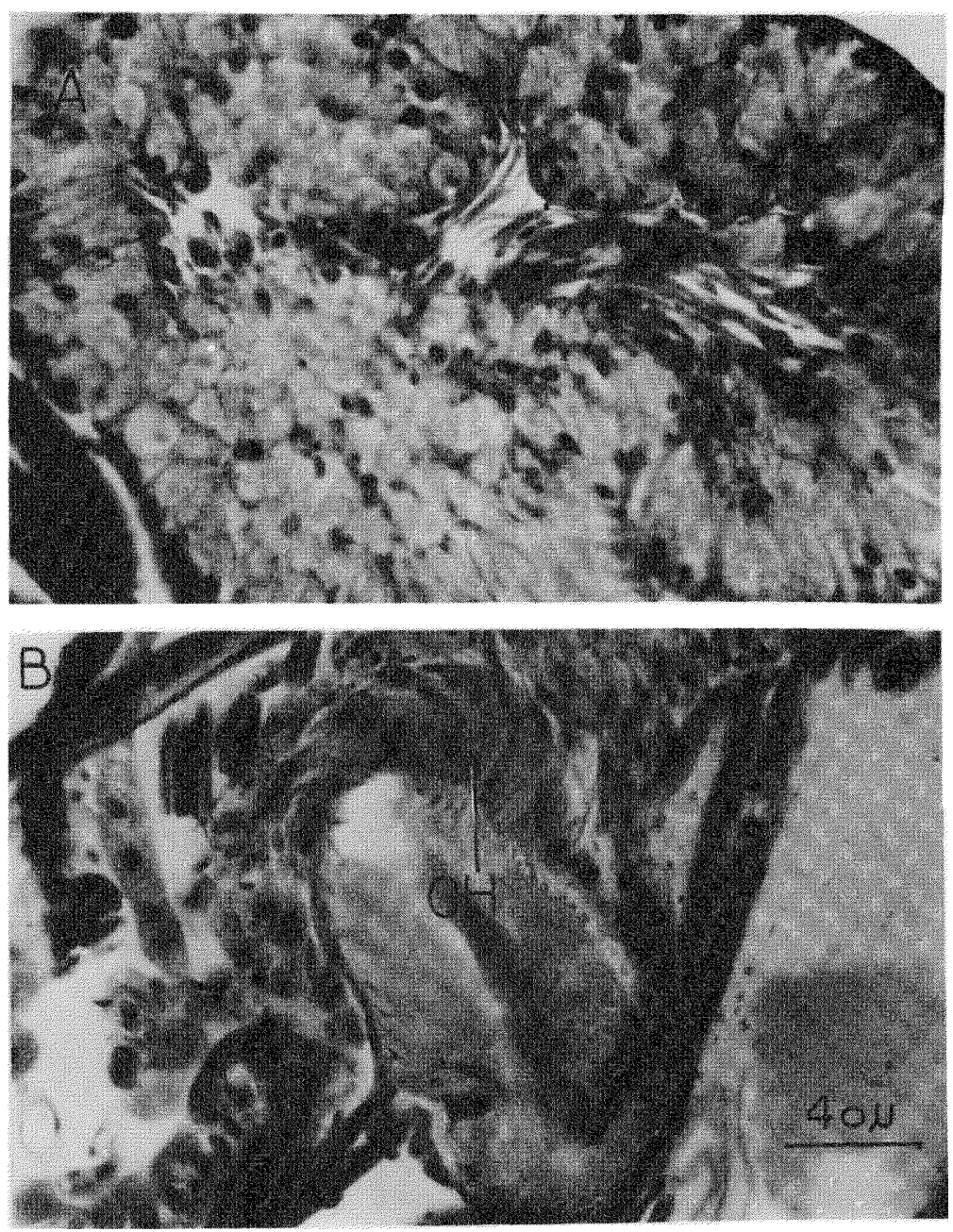

Fig. 11 A) Glandular complex in males of Pella humeralis, located dorsally of the genital chamber. B) Opening of the bundles of glandular channels through membrane; presumably into the genital chamber. 
know from observations by Wasmann, made more than 60 years ago, that these beetles are both fed and reared by their host ants. Both chemical and mechanical interspecific communication is involved in these unusual relationships. These aleocharines have broken the communication code of their host ants and are thereby able to live as parasites within the social system of the ant colony (Hölldobler 1967, 1970, 1971, 1972).

Species of the genus Pella are less advanced in their myrmecophilic relationships. Rather than occupy the brood chambers of the ant nest, they live as scavengers and predators in the peripheral zones around the nest, at the garbage dumps, and on the trunk routes. Some of the behavioral features of Pella, however, seem to be very similar to those of Atemeles and Lomechusa. In fact, these behavioral patterns might be preadaptations for the evolution of a highly advanced myrmecophilic relationship in the aleocharine beetles. In particular, the appeasement behavior appears to be an important prerequisite for living closely with ants. This "gentle" defense technique does not cause excitement in the ants, as a repellent defense would do.

Indeed, our observations indicate that Pella only rarely employ their strongly smelling tergal gland secretions when they are near the host ant colony. This defense system might be used more during the migration phase, when the beetles can be attacked by individual foraging ants. Similar results were previously obtained with Atemeles (Hölldobler 1970) and Lomechusa (Hölldobler unpublished). In the presence of their host ants these species use the appeasement defense almost exclusively.

The appeasement behavior also plays an important role during the adoption of Atemeles by their host ants. When encountering a worker of the host species near the ant's nest, the beetle first offers the appeasement gland complex (at the abdominal tip) to the ant. This apparently suppresses aggressive behavior in the ant; only then does the beetle lower its abdomen to permit the ant access to the adoption glands, which are located in the paratergites. The glandular openings are surrounded by bristles. These are grasped and used by the ant to carry the beetle into the brood chamber. While being carried, Atemeles adopts the same posture as that used by Pella during the "death feigning" behavior. As we have noted, the initially aggressive ants respond by either ignoring the beetles or else picking 
them up and carrying them around until they eventually discard them, usually unharmed, at the garbage dump. It is conceivable that the carrying posture of Atemeles has evolved from a defensive "death feigning" behavior employed by less advanced ancestral species.

Finally, Pella beetles do not have adoption glands associated with trichrome bristles. It is most likely, however, that the small clusters of glandular cells in the paratergites (for example in $P$. humeralis) represent morphological precursors of the massively developed adoption glands in Atemeles and Lomechusa.

\section{ACKNOWLEDGEMENTS}

We would like to thank Hiltrud Engel for technical assistance, Dr. V. Puthz for identifying the beetles, Ruiko Pierce for translating the work of Yasumatsu from Japanese into English, and Al Newton and Margaret Thayer for helping in disentangling the segmental morphology of Pella. This work was supported by grants from the Deutsche Forschungsgemeinschaft and National Science Foundation.

\section{REFERENCES}

Bernardi, R., C. Cardaini, D. Ghiringhella, A. Selva, A. Baggini, M. Payan 1967. On the components of secretion of mandibular glands of the ant Lasius (Dendrolasius) fuliginosus. Tetrahedron Lett. 40, 3893-3896.

Blum, M. S., R. M. Crewe, J. M. Pasteels

1971. Defensive secretions of Lomechusa strumosa a Myrmecophilous Beetle. Ann. Entomol. Soc. America 64, 975-975.

Blum, M. S., H. R. Herman

1978. Venoms and Venom Apparatuses of the Formicidae: Myrmeciinae, Ponerinae, Dorylinae, Pseudomyrmecinae, Myrmicinae and Formicinae; in Handbook of Experimental Pharmacology 48, pp. 801-869. Springer Verlag, Berlin, Heidelberg, New York.

Brand, J. M., M. S. Blum, H. M. Fales and J. M. Pasteels

1973. The Chemistry of the Defensive Secretion of the Beetle Drusilla canaliculata. J. Insect Physiol. 19, 369-382.

DUMPERT, $\mathbf{K}$.

1972. Alarmstoffrezeptoren auf der Antenne von Lasius fuliginosus (Latr.) (Hymenoptera, Formicidae). Z. Vergl. Physiol. 76, 403-425.

GöbWald, K., Kloft, W.

1958. Radioaktive Isotope zur Erforschung des Staatenlebens der Insekten. Umschau, 58, 743-745. 
HöLLDOBLER, B.

1967. Zur Physiologie der Gast-Wirt-Beziehungen (Myrmecophilie) bei Ameisen. I. Das Gastverhältnis der Atemeles- und Lomechusa Larven (Col. Staphylinidae) zu Formica (Hym. Formicidae). Z. Vergl. Physiol. 56, $1-21$.

1970. Zur Physiologie der Gast-Wirt-Beziehungen (Myrmecophilie) bei Ameisen. II. Das Gastverhältnis des imaginalen Atemeles pubicollis Bris. (Col. Staphylinidae) zu Myrmica und Formica (Hym. Formicidae). Z. Vergl. Physiol. 66, 176-189.

1971. Communication between ants and their guests. Sci. American, March 1971. 86-91.

1972. Verhaltensphysiologische Adaptationen an ökologische Nischen in Ameisennestern. Verhandlungsbericht der Dtsch. Zool. Ges. 65. Jahresvers. $137-143$.

JORDAN, K. H. C.

1913. Zur Morphologie und Biologie der myrmecophilen Gattungen Lomechusa und Atemeles und einiger verwandter Formen. Z. Wiss. Zool. 107, 346-386.

KISTNER, D. H.

1971. Studies of Japanese Myrmecophiles Part I. The Genera Pella and Falagria (Coleoptera, Staphylinidae) in Entomological Essays to Commemorate the Retirement of Professor K. Yasumatsu, pp. 141-165. Hokurynkan Publ. Co. Ltd. Tokyo.

1979. Social and Evolutionary Significance of Social Insect Symbionts. In Social Insects (vol I) (ed. H. R Hermann) pp. 340-413, Academic Press, Inc. New York, San Francisco, London.

Kistner, D. H., M. S. Blum

1971. Alarm Pheromone of Lasius (Dendrolasius) spathepus (Hymenoptera: Formicidae) and Its Possible Mimicry by Two Species of Pella (Coleoptera: Staphylinidae). Ann. Entomol. Soc. America 64, 589-594.

KLOFT, W.

1959. Direktes und indirektes Verfahren zur Messung der Beta-Strahlenabsorption von kleinen Gewebeschichten an Insekten. Glas-Intr. Techn. 3, 79-82.

Koblick, T. A., D. H. KistNeR

1965. A revision of the species of the genus Myrmechusa from tropical Africa with notes on their behavior and their relationship to Pygostenini (Coleoptera, Staphylinidae). Ann. Ent. Soc. Amer. 58, 28-44.

Kolbe, W.

1971. Untersuchungen über die Bindung von Zyras humeralis (Coleoptera, Staphylinidae) an Waldameisen. Entomol. Blätter 67, 129-136.

Kolbe, W., M. G. Proske

1973. Iso-Valeriansäure im Abwehrsekret von Zyras humeralis (Col. Staphylinidae). Entomol. Blätter 69, 57-60.

Maschwitz, U., B. Hölldobler

1970. Der Kartonnestbau bei Lasius fuliginosus Latr. (Hym. Formicidae). Z. Vergl. Physiol. 66, 176-189. 
MOORE, B. P.

1968. Studies on the chemical composition and function of the cephalic gland secretion in Australian termites. J. Insect Physiol. 14, 33-39.

Pasteels, J. M.

1968. Le système glandulaire tégumentaire des Aleocharinae (Coleoptera, Staphylinidae) et son évolution chez les espèces termitophiles du genre Termitella. Arch. Biol. (Liège) 79, 381-469.

Patrizi, S.

1948. Contribuzioni alla conoscenze delle formiche e dei mirmicofile dell' Africa orientale. V. Note etologiche su Myrmechusa Wasmann (Coleoptera, Staphylinidae). Bull. Ist. Entomol. Univ. Bologno 17, 168-173.

Quilico, A., F. Piozzi, M. Pavan

1957. The structure of dendrolasin. Tetrahedron 1, 177-185.

RATHMAYER, W.

1962. Methylmethacrylat als Einbettungsmedium für Insekten. Experientia (Basel) 18, 47-48.

SchildKnecht, H., H. Krämer

1962. Zum Nachweis von Hyrdochinonen neben Chinonen in den Abwehrblasen von Arthropoden. Z. Naturforsch. 176, 701-702.

WASMANN, E.

1886. Über die Lebensweise einiger Ameisengäste. Dtsch. Entomol. Zeitschr. 30, 49-66.

1920. De Gastpflege der Ameisen. Gebrüder Borntraeger, Berlin.

1925. Die Ameisenmimikry. Gebrüder Borntraeger, Berlin.

1930. Zur Biologie von Myrmedonia (Zyras). Entomol. Berichte 8, 150-151. WILSON, E. O.

1971. The Insect Societies. The Belknap Press of Harvard University Press, Cambridge, Mass.

YASUMATSU, $\mathrm{K}$.

1937. Lasius fuliginosus (Latreille) var. spathepus (Wheeler and its synechttrans Zyras comes Sharp and Zyras cognathus Märkel var. japonicus Sharp. Nippon no Kochu 1, 47-51. 

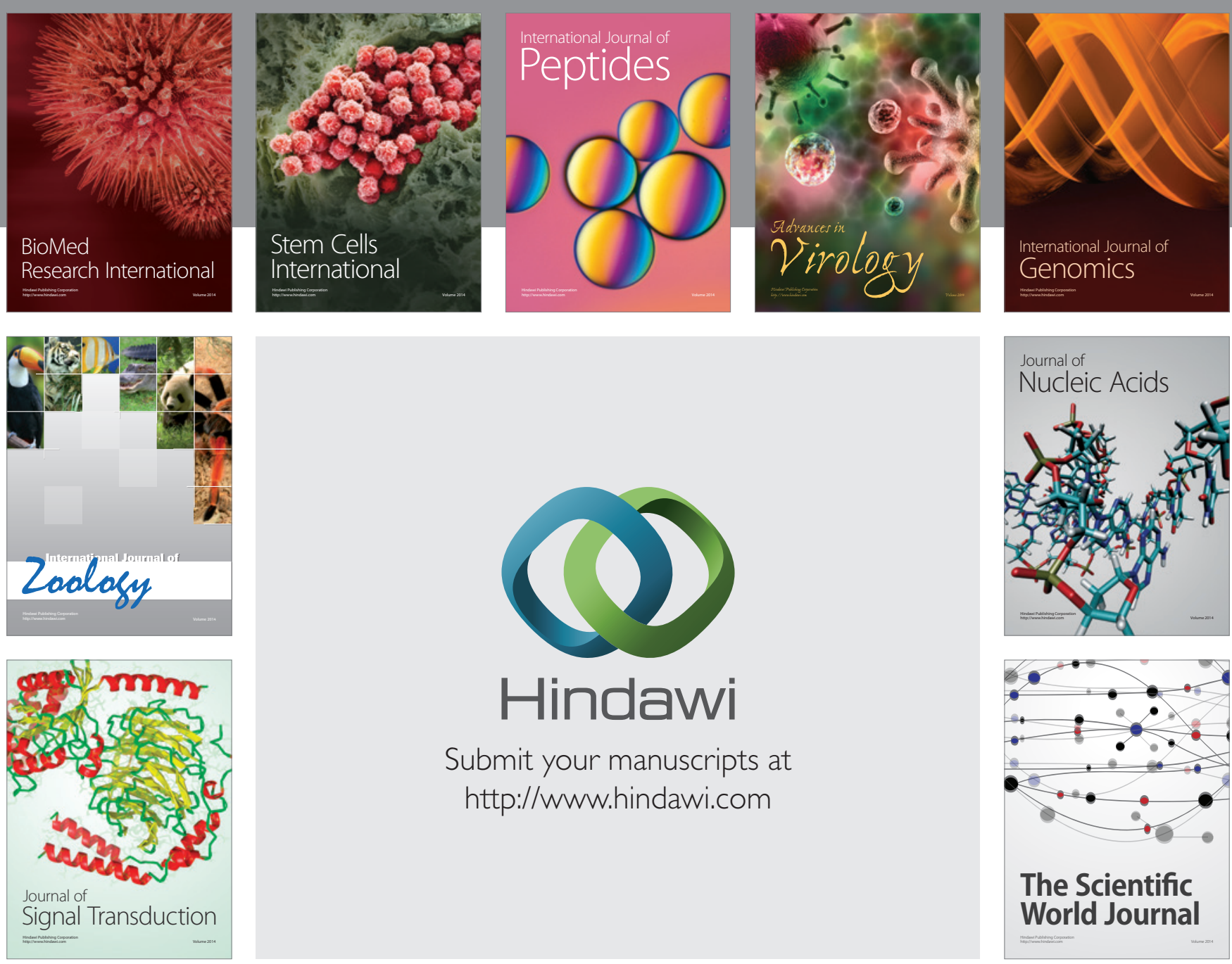

Submit your manuscripts at

http://www.hindawi.com
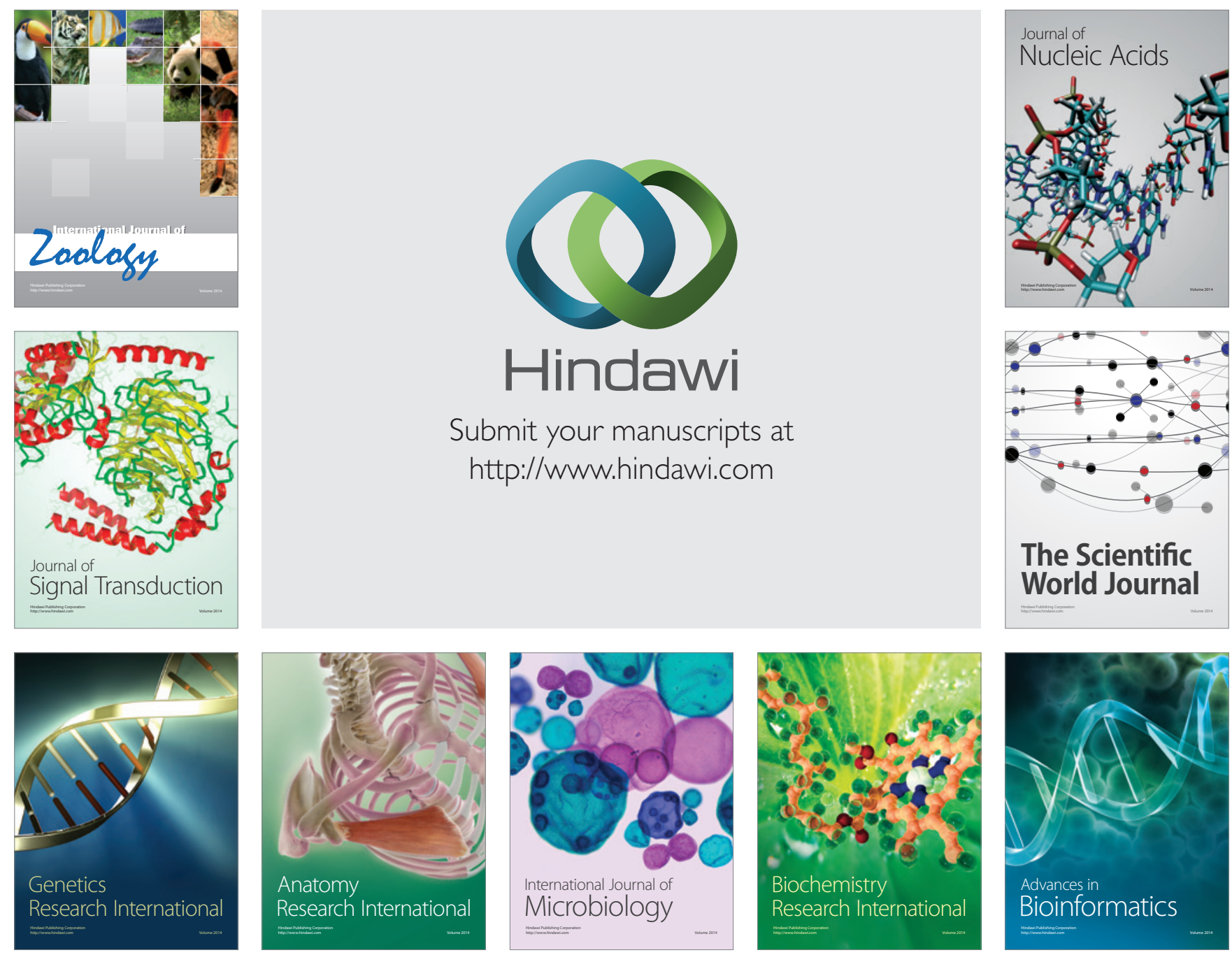

The Scientific World Journal
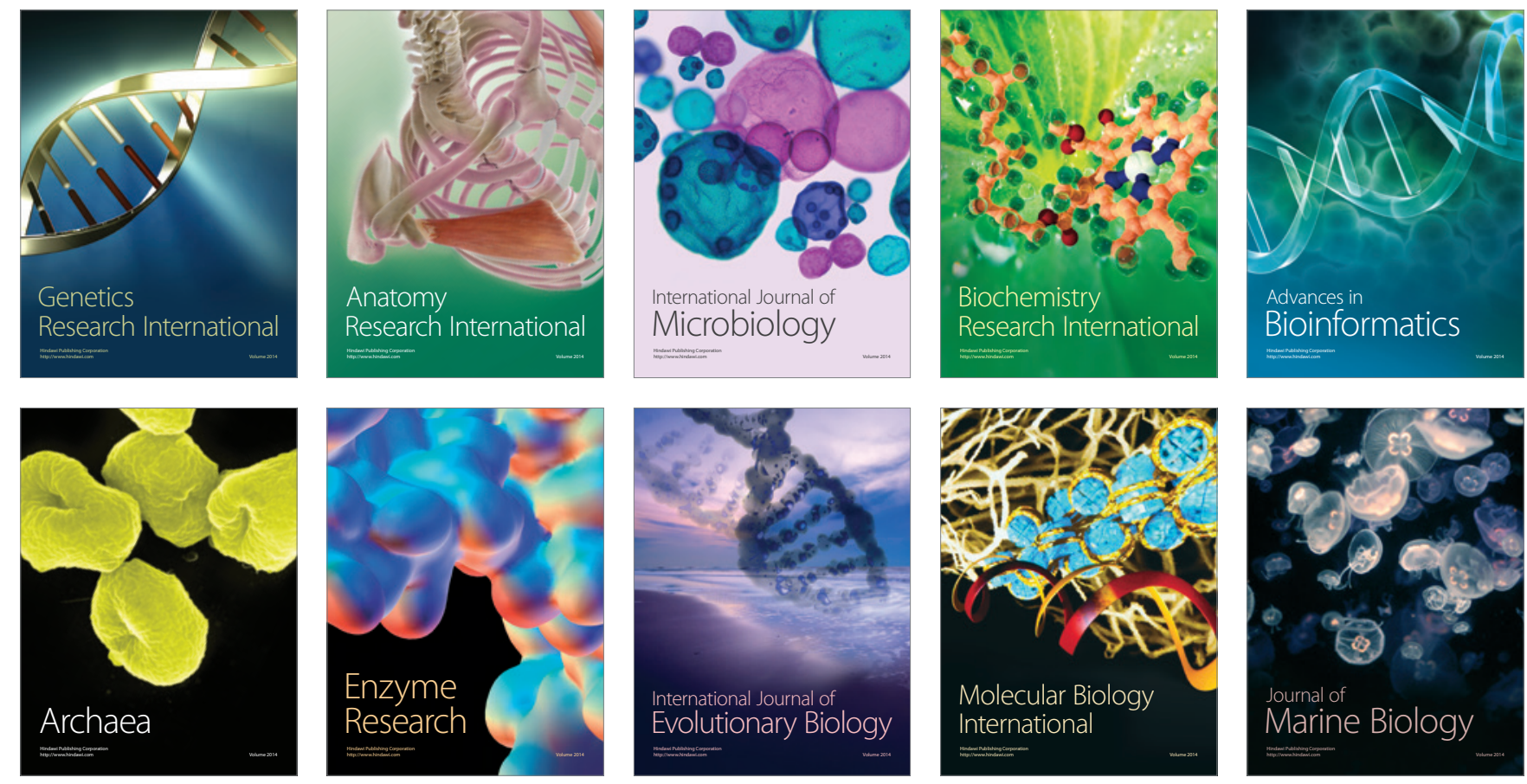